\title{
Understanding Fansub as One of the Audiovisual Translation Methods
}

\author{
LIEW ZHE RONG ${ }^{1,2}$ \\ *HASURIA CHE OMAR ${ }^{1}$ \\ ${ }^{1}$ School of Humanities, Universiti Sains Malaysia, 11800 USM Pulau Pinang, Malaysia \\ Current affiliation: \\ ${ }^{2}$ Thomson Reuters Penang, Bandar Bayan Baru, 11900 Bayan Lepas, Pulau Pinang, Malaysia \\ *Corresponding author: hasuria@usm.my
}

Published online: 26 September 2018

To cite this article: Liew, Z.R. and Che Omar, H. 2018. Understanding fansub as one of the audiovisual translation methods. KEMANUSIAAN the Asian Journal of Humanities 25(2):109-127, https://doi. org/10.21315/kajh2018.25.2.6

To link to this article: https://doi.org/10.21315/kajh2018.25.2.6

\begin{abstract}
The advancement of multimedia and internet technologies has led to the development of a new form of communication known as fansubbing that connects anime fans from around the globe. Fansubbing can be regarded as a form of collaborative practice because it provides anime fans the opportunity to explain the infusion of foreign cultural elements in local culture, thus enabling the target audience to better understand the anime shows that they are watching. As a translation method, fansubbing also allows anime fans to share their knowledge and interests through a free digital network. In relation to this context, this paper aims to discuss the position of fansubbing as a community's contribution towards understanding anime in a different culture. The discussion is mainly centred upon the ideas posited by Hatcher (2005) and O'Hagan (2009) on fansub for Japanese anime and technology, Diaz-Cintas and Muñoz Sánchez's (2006) and Pérez-González's (2007, 2012) on the conventional subtitling and fansubbing approaches, and Chiaro's (2008) on viewers experience. Despite the differences between fansub activities and the conventional subtitling practices, this new experience somehow illustrates a practical combination of these two subtitling approaches. This paper is expected to contribute to a more in-depth understanding of fansub as an avenue for viewers to share their cultural knowledge with the target audience who have minimal knowledge about the source language, culture and the background of the anime. In addition, the paper will also seek to understand the potential reception for anime amongst the target audience due to the effects of fansubbing.
\end{abstract}

Keywords and phrases: anime, audiovisual translation, fan subtitling, semiotic channel, subtitling 


\section{Introduction}

"Fansub" is a portmanteau of the word "fan", referring to fan(atics) and "sub" which is an abbreviation of subtitling or subtitles. ${ }^{1}$ As gleaned from this portmanteau, fansub refers to subtitles produced by fans themselves for television programmes that they are interested in. The development of fansub can be attributed to the global spread of anime pop culture, i.e., Japanese language animation series from Japan vis-a-vis the development of multimedia and internet technologies. The fansub movement is believed to have begun in the 1980s in the United States by anime fans who had produced subtitles (using rented subtitling equipment) for original Japanese language anime shows on video home system (VHS) tapes that were directly imported (Hatcher 2005, 549). These subtitled self-produced copies were mainly shared among anime club members in the universities or during special screenings at anime fairs or other related activities in the United States (ibid.). Apart from being the sole medium in which anime fans could enjoy original anime series in the Japanese language, one of the major factors that drove the development of fansub during that time was the fans' dissatisfaction with the local distribution/marketing companies who had used dubbing or voice-overs for the Japanese anime series. Studies have reported that these companies had also edited or censored elements that were deemed as inappropriate or unsuitable for local culture before the products were sold or circulated in the domestic market (PérezGonzález 2007, 263; O'Hagan 2009, 100). Disillusioned with such practices, anime fans who desired a more authentic viewing experience began to produce their own subtitles for anime series on VHS tapes that they had bought from Japan.

Fansub which had rapidly gained popularity since the 1990s has become more widespread today due to the advancement of multimedia, latest computer software as well as new broadband internet technologies (Hatcher 2005, 550; O'Hagan 2009, 94-102). More importantly, the borderless world of the internet has successfully connected groups of anime fans across the globe, turning anime pop culture into a global phenomenon. Hence, every piece of information and material related to anime is easily accessed by anime fans across the globe who connect and share information and experience with one another through forums, Internet Relay Chat (IRC), chatgroups, social media portals, etc. This eventually has led to the establishment of fansub groups which primarily exist to create subtitles for popular anime series, using open source subtitling softwares that are available online. Eventually, these subtitled digital video files are distributed freely to other fans through peer-to-peer (P2P) networks or BitTorrent. These fans paved the way for a collaborative relationship of "prosumers" (Toffler 2006 as cited in Bold 2011), a term used to refer to groups of consumers that craft their own products or provide services based on their own requirement, needs and preferences. Meanwhile, other 
anime fans who are not involved in providing the subtitles can also voice their opinion or post comments directly to the fansub groups through forums, IRC and other social media platforms (Rush 2009, 6-13). In such a business platform, products and services are freely shared among members. Based on current developments, fansubbing is believed to have the potential to form its own unique approach in the production of subtitles for anime series in future.

\section{Key Features of Fansub}

Fansub is vastly different from conventional or professional subtitling with differences being easily observable from the onset of the workflow ${ }^{2}$ until the final product. It also diverges from the norms and practices of conventional subtitling ${ }^{3}$ by featuring a combination and harmonisation of different subtitling approaches within a fansub framework (Diaz-Cintas and Muñoz Sánchez 2006, 51).

\section{Workflow in the production of fansub}

The production of fansub often involves group collaboration and distribution of tasks among members of fansub groups depending on their skills and capabilities in language or technical knowledge. A number of previous works (Diaz-Cintas and Muñoz Sánchez 2006, 38-43; Pérez-González 2007, 266-269) have elaborated on the various tasks and roles within a fansub group as well as the workflow in a typical fansub production. A fansub group commonly consists of:

1. Raw/source material provider: The provider of raw/source material recording is involved in obtaining source material, for example, recording of episodes of anime series from television or DVD, in which its audio is in the source language. If the raw or original material is in Japanese (which is always the case for anime series), English language subtitles are inserted after the translation process by fansub groups. Raw/source material providers often obtain their source materials using digital video recorders which are connected directly to television. The video will record the anime series broadcasted on the television leading to the production of digital copies. Direct recording from the television channel is carried out for most of the latest anime series currently broadcasted on both terrestrial and satellite television locally. Digital recording can also be obtained from DVDs particularly for full-length animation movies that are released in the DVD form after having been screened in cinemas. Original video animations (OVA), especially anime series, are generally not broadcasted on television; instead they are marketed in the form of DVD. Anime series that have been broadcasted on television could also be re-released in DVD 
form after they are remastered with better visual or audio quality (such as using high definition, HD) as well as other additions that differ from television broadcasts.

2. Translator: The translator in a fansub group plays the same role as any conventional subtitlist, namely to produce target language translation from the source language to be used as subtitles. However, at this particular moment, knowledge of technical skills is not considered mandatory for a translator in a fansub group. For them, the primary focus is to produce subtitles. The translators will normally watch the digital source recording that has been obtained from raw/source material provider a number of times, so that they are able to produce a complete transcription of the characters' dialogues within the recording. Simultaneously, they would also try to identify non-verbal elements that may exist in the selected scenes in the recordings. The translator who is involved in producing the English version is normally not a native speaker of English. Translating work is usually undertaken by native speakers of Japanese (Diaz-Cintas and Muñoz Sánchez 2006, 45). This is largely due to the inavailability of English language speakers who also have in-depth knowledge and understanding of Japanese culture. However, the trend is likely to change with the spread of cultural knowledge and awareness (O'Hagan 2009, 101) and increase in the number of people learning Japanese as a foreign language. Fansub groups who work in other languages, are also dependent on English fansub as the pivot language and the quality of their work is highly dependent on the accuracy of the English fansub (Diaz-Cintas and Muñoz Sánchez 2006, 38-39, 49-50).

3. Timer: The timer plays the role of setting the time code for subtitles (that has been translated into text files by translators) to appear in the digital recording by utilising specific softwares such as Sub Station Alpha (SSA), Aegisub, Sabbu, Jaco Sub and others (Diaz-Cintas and Muñoz Sánchez 2006, 39). The timer ensures that the time taken for the appearance of subtitles is aligned or coincides with the spoken dialogue in a scene.

4. Typesetter: The typesetter is responsible for selecting and determining the font types, sizes and colours that are suitable for the anime series recording. The selection is not just for the spoken dialogue of characters but also for the lyrics of the opening and closing songs, acknowledgements or end credits and non-verbal elements that may appear in certain scenes. The choice of font size, type and colours for subtitles of the opening and closing songs and the description for the non-verbal elements is dependent 
on the interplay between the subtitles and overall aesthetic features of certain scenes in the anime series. For that purpose, the typesetter often uses specific softwares such as TextSub or SSA to modify the presentation of subtitles directly onto the recording to ensure that the font types, sizes and colours appear seamlessly in the digital recording of the anime series (Diaz-Cintas and Muñoz Sánchez 2006, 39, 41; Pérez González 2007, 267).

5. Editor: The editor also plays a key role in ensuring the quality control of fansub productions before they are ready to be released to fans/viewers. Quality control in fansub is focused on a number of key issues, mainly to ensure that the subtitles are grammatically correct and appears natural in its presentation (as the translators involved are often not native speakers of English). In addition, it also ensures that the duration of the subtitles appearance on screen coincides with the characters' dialogues and that the dialogues' sound natural in their presentation. Knowledge of Japanese language and culture is an additional advantage that will help the editor in ensuring that the explanation which appears in the subtitles (especially for parts containing Japanese cultural elements) can be clarified using information gathered through additional research. This will help to reduce or eliminate irregularities in the subtitles. Any mistakes that occur are highlighted by group members in the fansub group or corrected on the subtitles' text files.

6. Encoder: At the final stage in the production of fansub, the encoder is tasked to combine the subtitles text file which has been timecoded by the timer and typesetted by the typersetter using software to create the final product, namely a digital file recording of Japanese anime series with subtitles. The encoder also compresses the size of the digital fansub file through file compression to enable it to be easily and quickly distributed through the internet. The distribution of fansub files is done using a number of key methods, namely through BitTorrent, a P2P software or IRC.

7. Other fans: Members of fansub groups, who are not directly involved in the production of fansub, can still contribute to the production of fansub by posting feedback, suggestions and critique of fansub works through the following medium: forums, chat room, fan group/fansite or direct communication through e-mail, IRC and official website (Rush 2009, 7-8). Any valuable suggestions and feedback from fans are often taken into consideration with improvements made on the next fansub work or episode. Other fans also play an important role in the distribution of fansub 
works especially when using P2P software such as BitTorrent. Fans who have downloaded a fansub work through BitTorrent are encouraged to keep their BitTorrent software running as any file successfully downloaded by fans will become the seeder in BitTorrent, thus ensuring the download speed of BitTorrent users in which their download is not yet completed (also known as leecher) to be faster by contributing data to other users (a key principle of P2P models). Fans that have downloaded digital fansub files can also upload the files onto other files and video hosting websites such as Megaupload, YouTube, etc. to provide alternative methods for the fans to download and enjoy the product of the fansub works.

While such task division is common within the fansub group, sometimes a member of a group may take on a number of tasks simultaneously based on their capabilities, skills and willingness. For fansub groups that work collaboratively on a number of anime series at the same time, often have more members to share the workload. The opportunity for a fan to be involved in the production of fansub is always available based on his/her willingness, skills and capabilities. In sum, the whole procedure involving the production of fansubs is made possible by multimedia and broadband internet technologies which foster a collaborative relationship leading to quality production that is similar to or even better than anime series that undergo the conventional method for the creation of subtitles. In addition, fansub productions are less time consuming and thus, the turnover time is much shorter and subtitling work is usually completed within a day or two (O’Hagan 2009, 101).

\section{Specific subtitling approaches commonly used in fansub}

Previous researches (Ferrer-Simo 2005, 30-42; Diaz-Cintas and Muñoz Sánchez 2006, 45-47; Pérez González 2007, 270-272) have elaborated on a number of key features in terms of the differences in approaches between a fansub and conventional subtitles. The following are the key features of the approaches adopted in fansub works:

1. Variety of font types, sizes and colours for subtitles: A "fansubber" often uses a variety of font types, sizes and colours in their work which are not based on conventional requirement. Instead, their selection is based on their own creative feel. Their practices are different from conventional subtitling as their selections are determined by subtitling softwares or machines (Wan Ida Rahimah 2007, 49, 51) which are in agreement with professional subtitling guidelines and rules (Karamitroglou 1998). Such 
creativity can be clearly observed at the opening or closing soundtracks of an anime series. The font types and colours used for the production of subtitles are commonly aligned with the overall aesthetics of the opening and closing soundtracks. The general trend is to use different font colours for the original lyrics (in Japanese language), its transliterations as well as its translations. Furthermore, karaoke effects (lyrics shown are bold as the song is sung) are also given for the subtitles of opening and closing soundtracks, inviting viewers to sing along with the songs.

Besides the opening or closing song sections, the variety in font type colours and sizes in fansub works can also be observed when the fans translate non-verbal elements (such as writings, signboards, etc.) that are not part of the dialogues which appear in particular scenes. The font type, size and colour used in the translation of the non-verbal elements are usually aligned with the overall aesthetics of the scene. These selections are also made to ensure that the non-verbal elements appear natural to ensure that they do not affect the appreciation of fans or viewers when watching the anime series. Different font colours are also used when a particular scene has two or more characters who speak simultaneously thus distinguishing speech of different characters in the same scene. Such an approach is similar with new approaches that began to appear in the subtitling of foreign language films in DVD format (Diaz-Cintas 2005, $8-9)$. Figures 1 and 2 show various examples of such features in the production of fansub.

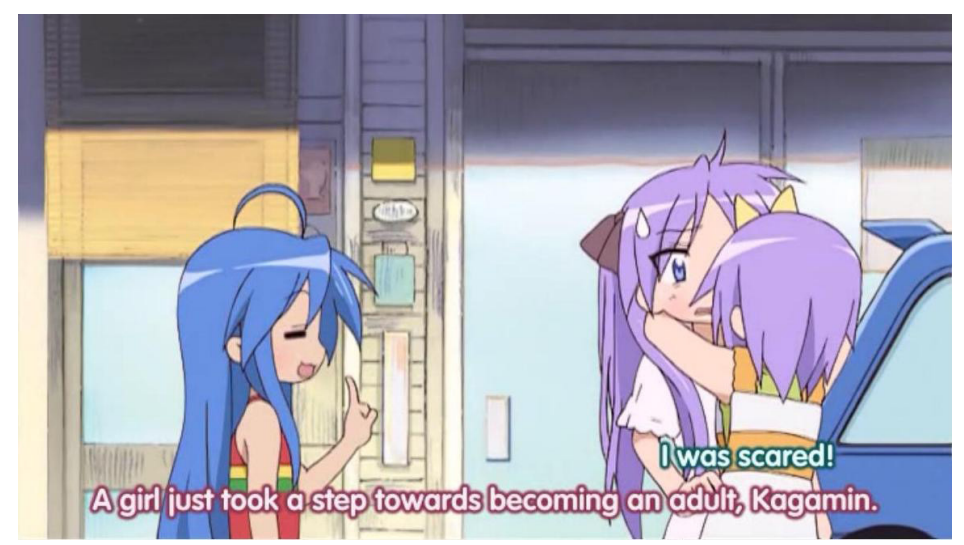

Figure 1. Dialogues of different characters that appear simultaneously are given different colours to distinguish them. Green is used for the shorter dialogue while pink is used to show the main dialogue. 


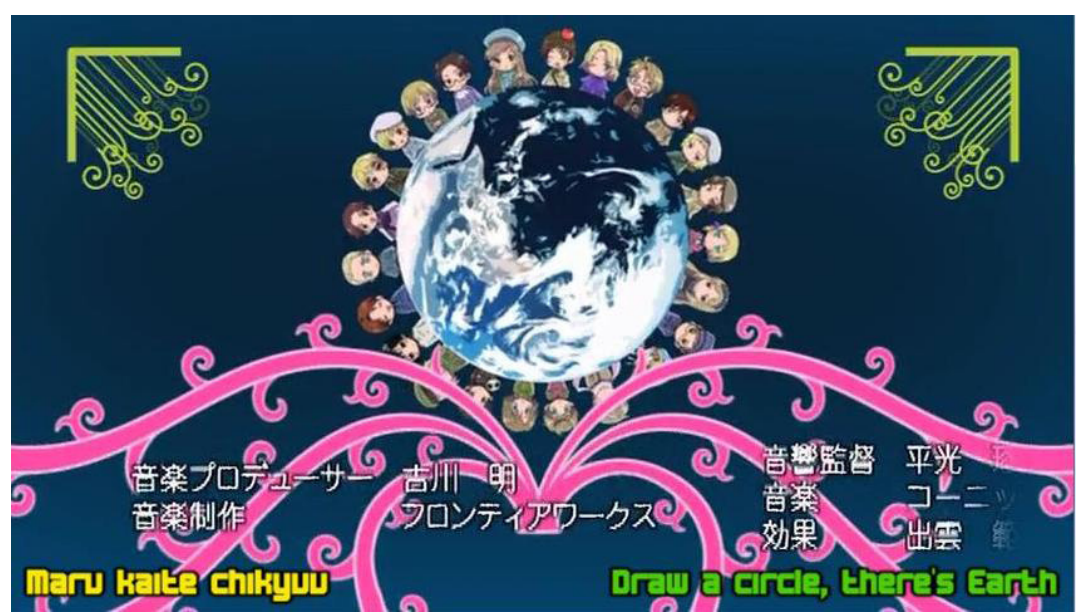

Figure 2. Different font types and colours are used to produce subtitles for opening and closing songs of the anime series in order to distinguish the transliteration of song lyrics from the translation of song lyrics.

2. Usage of footnote/translator's note as well as preservation of gloss/foreign language elements in subtitles: In comparison to conventional subtitlists who often omit foreign cultural elements in the subtitles, mainly because of space constraints, fansubbers often retain foreign cultural elements that appear in the characters' dialogues in an anime series. The footnote or translator's note is used to explain foreign cultural elements. Footnotes or translator's note are used in a number of approaches in fansub work. The most common approach used is to provide footnotes or translator's note on the top section of the screen in tandem with the dialogues (Figure 3).

The subtitles that appear in a particular scene will provide a brief explanation of foreign cultural elements in the characters' dialogues. If there are foreign cultural elements that are too complicated (due to being an integral part of the overall storyline or others) to be explained using short notes on screen, fansubbers may insert the translator's note which contains further explanation at the very end of the particular anime episode, that is right after the ending of the song section. This is undertaken to provide the opportunity to learn more about these foreign cultural elements. This will help viewers to have a better understanding of the anime series for future viewing. 


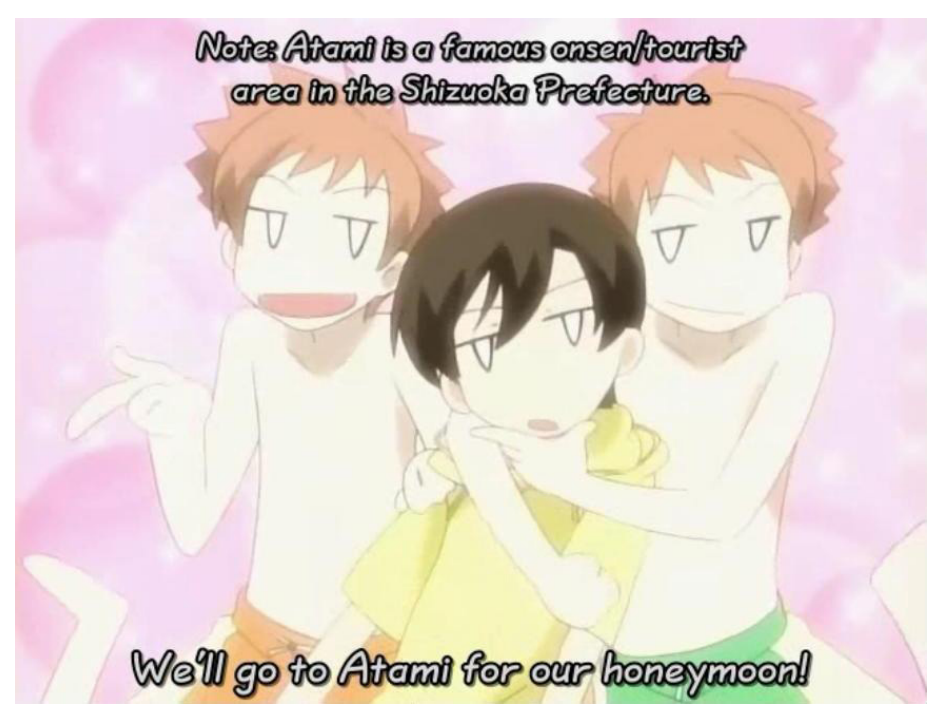

Figure 3. Translator's note on the top section of this screenshot is used to inform the viewers about Atami (http://wikitravel.org/en/Atami), a resort area in Japan which is famous for their hotsprings.

3. Layout, positioning and presentation of subtitles: In comparison to the conventional subtitles that are often positioned at the bottom part of the screen, fansubbers will fully utilise all the spaces available on screen as long as the subtitles produced do not disrupt viewers' appreciation of the anime series. While the bottom section of the screen is used to accommodate the translation for the characters' dialogues, the top section of the screen is often used to insert footnotes or the translator's note. The notes are considered necessary when a foreign cultural element requires further explanation to enable viewers to fully comprehend and appreciate certain scenes in the anime series. Subtitles for non-verbal elements apart from characters' dialogues (signboard, writings on screen, etc.) that appear in certain scenes are often explained using notes that are positioned at the top section of the screen. They could also exist together with the nonverbal elements directly on screen. Such subtitles are often modified in terms of font types, colours, font sizes and layout (such as vertically aligned, italicised, bolded, etc.) so that they are aligned to the particular scene to blend in aesthetically with non-verbal elements. Such an approach is referred to as "scenetiming" (Pérez González 2007, 271-272) and most subtitling softwares used by fansubbers possess that capability (DiazCintas and Muñoz Sánchez 2006, 40). Figure 4 exhibits these features. 


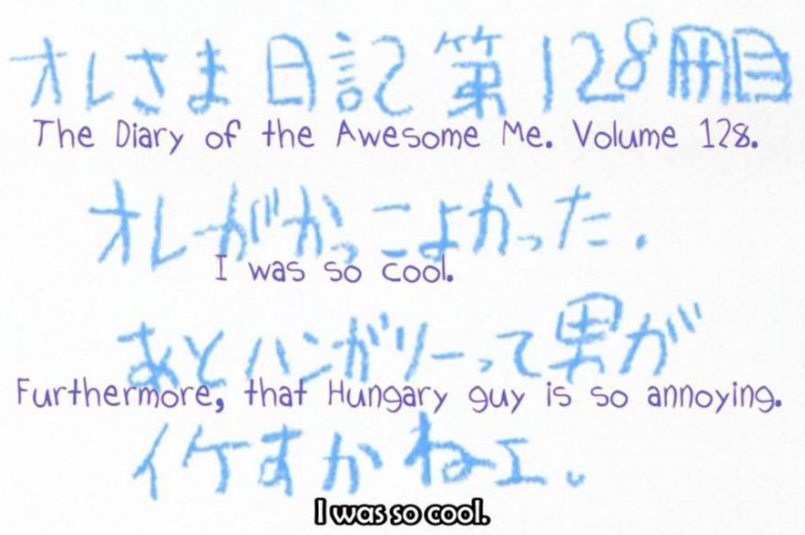

Figure 4. The translation of non-verbal element in this scene appears simultaneously with the non-verbal element itself; font types and colours modified in order to appear naturally. In this excerpt, the font chosen is similar to crayon writings.

4. Information about fansubbers within fansub works: In contrast to conventional subtitling that often minimises the existence of subtitlists (often only noted in name at the very end of a television programme) within its subtitling works, fansubbers are often enthusiastic in highlighting their involvement in the production of fansub for the anime series they have participated in. Their presence can be identified through the insertion of the names of group members involved in the production of fansub in the opening or closing section of the anime series, based on their tasks or roles. The presentation of credits is also aligned with the overall aesthetic appearance of the opening or closing section of the anime series. The credit sequence, will normally display the address of the fansub groups' websites, e-mails or IRC for communication purposes. In addition, viewers are also reminded not to resell the product of fansub for their own personal profit. Fansub works are meant to be shared for free and not to be sold for monetary gain. Apart from the name of fansubbers that appear in the credit, occasionally the presence of the fansubbers may also be observed through their personal opinions or commentaries which commonly appear in the footnote or translator's note. Commentary and opinions by fansubbers can also be hilarious. Figure 5 exemplifies the personal opinion and commentary by fansubbers that appear in the footnote or translator's note. 


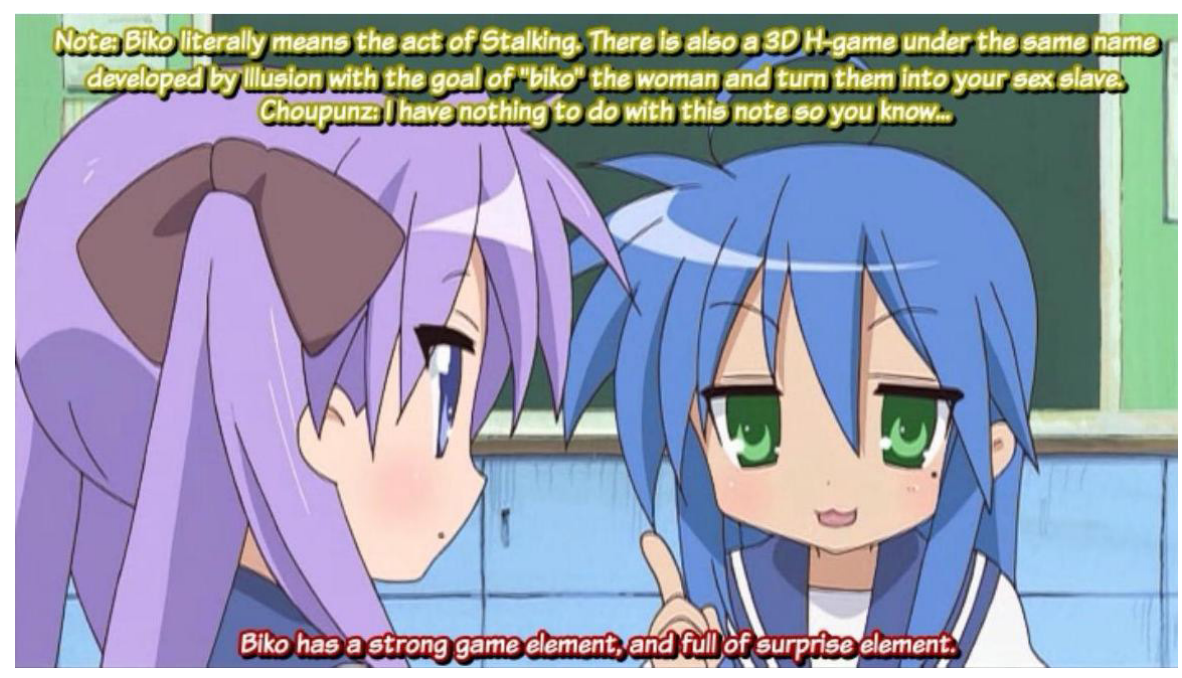

Figure 5. A member of a fansub group provides his/her own opinion about topics explained in the translator's note.

Figures 6(a) and 6(b) show the insertion of the name of the fansub group in a particular scene.

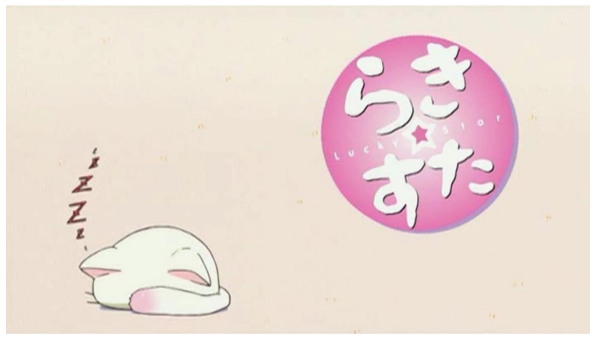

(a)

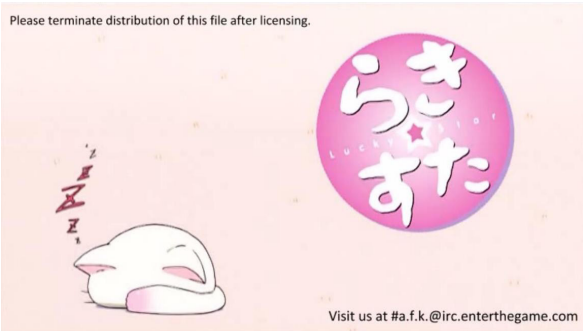

(b)

Figure 6. The empty space within the original scene (a) has been used by a fansub group in (b) to include their IRC address as well as a reminder to fans and viewers.

The observation shows that the features and approaches specific to fansub works as discussed above are common in the world of fansub. However, fansub groups are free to choose any available approaches to produce fansubs based on their own requirements and skills. The differences in the working features between fansubs and conventional subtitles can be summarised in Table 1 . 
Table 1. A comparison of features between conventional subtitles and fansub works

\begin{tabular}{lll}
\hline Features & \multicolumn{1}{c}{ Conventional subtitles } & \multicolumn{1}{c}{ Fansub } \\
\hline $\begin{array}{l}\text { Font type, size and } \\
\text { colour }\end{array}$ & $\begin{array}{l}\text { Consistent font type such as } \\
\text { Helvetica and Arial. Pale white } \\
\text { in colour with grey background. } \\
\text { Often set by subtitling software. }\end{array}$ & $\begin{array}{l}\text { The usage of font type, size and } \\
\text { colour in subtitles may differ } \\
\text { based on work requirement and } \\
\text { creativity. }\end{array}$ \\
$\begin{array}{l}\text { Preservation of gloss/ } \\
\text { foreign language } \\
\text { elements within } \\
\begin{array}{l}\text { Fubtitles and usage of } \\
\text { footnote/translator's } \\
\text { note }\end{array}\end{array}$ & $\begin{array}{l}\text { often dropped. No additional } \\
\text { explanations using footnote/ } \\
\text { translator's note. }\end{array}$ & $\begin{array}{l}\text { Foreign language elements } \\
\text { commonly preserved. Footnotes/ } \\
\text { translator's notes are used and } \\
\text { appear on relevant scenes. }\end{array}$ \\
presentation of subtitles & $\begin{array}{l}\text { Consistent, usually at the bottom } \\
\text { part of the scene. }\end{array}$ & $\begin{array}{l}\text { May change. Also translates } \\
\text { non-verbal elements in a form } \\
\text { appropriate with the scene } \\
\text { involved. }\end{array}$ \\
$\begin{array}{l}\text { Information about } \\
\text { subtitlists }\end{array}$ & $\begin{array}{l}\text { A mere mention of name at the } \\
\text { end of the programme. }\end{array}$ & $\begin{array}{l}\text { Fansub groups inserted in the } \\
\text { opening and closing section. May } \\
\text { occasionally include personal } \\
\text { opinions of fansubbers. }\end{array}$ \\
\hline
\end{tabular}

\section{General Subtitling and the Challenges of Fansubbing Activities}

The various norms, conventions and guidelines set by professional subtitling industry are meant to ensure accuracy and consistency in the production of subtitles for television programmes and films so that viewers can comprehend the content effectively and naturally without distractions. However, the assumption is that these norms, conventions and guidelines are good for all products (i.e., one size fits all). From the perspective of film productions, norms, conventions and guidelines developed in the professional subtitling industry are based on the narrative and presentation style of Western films. This developed initially in the United States and subsequently spread across the globe due to the influence of Hollywood blockbuster movies (Pérez-González 2007, 273). Hence, the framework that was designed for Hollywood films is not suitable to be used in translating Japanese anime series that are on a different narrative language and culture. Anime consists of various elements from Japanese manga or comics. These influences such as comic freeze frame and visual insertions that provide detailed imagery of narrated culture, highlights the importance of exposure to Japanese culture for viewers to understand any specific reference that appears in an anime series (Pérez González 2007, 262-263; Chiaro 2008, 142). The application of visual-verbal elements beyond spoken dialogues of characters to capture and present certain messages 
and the intended effect also play unique roles within the anime genre (O'Hagan 2010, 75-78).

These key features of anime along with the unique visual conventions and filming syntax have affected viewers' experience outside Japan. In other words, "local" form of audiovisual products which can be accessed beyond its original locale due to globalisation began to put pressure on the audiovisual translation industry (regardless of subtitlings or dubbings) that have conformed to Western filming for a long period of time. This led to the re-examination of previous norms and conventions in translation (Pérez-González 2007, 263).

Audiovisual translation has long been seen as less important compared to other conventional translation products, such as the translation of document or books. This is one of the reasons that caused audiovisual translation industry to remain stagnant for so long, even though it is the most widely distributed and consumed form of translation (Chiaro 2008, 241). Subtitling or dubbing in an audiovisual product is often insignificant as the existing norms and conventions in audiovisual translation will always ensure that the product does not disrupt the viewers' attention and focus. This situation has caused the translation product to be passively consumed by the viewers who have, over time, become accustomed to this form of audiovisual translation (Chiaro 2008, 245). Furthermore, as the shows are only broadcasted once for a short duration, viewers do not have any choice, but to watch the subtitled programmes regardless of whether they are satisfied with the translations (subtitles) or not. The audience normally has limited avenues to provide their feedback about the quality of the subtitles. As a result, the quality of audiovisual translation and its effect on the audience has not received much attention from any consumer research (Chiaro 2008, 250).

However, this does not mean that viewers are not conscious or aware of the poor quality of the translation in the programmes they are viewing. Previous studies, for instance Bucaria (2008) in his critique of the use of dubbing in Italy, claim that viewers are aware of the glitches in the translation product they are watching but often regard such blemishes as inevitable (Chiaro 2008, 254). However, the development of specialty television channels that specialise in specific genres, language and/or culture has made audiovisual translation a necessity to capture the increasingly specified and varied target viewers (Diaz-Cintas 2008, 7; Gambier 2009, 41-42). In addition, audiovisual translation must also be sensitive and should focus on the shift in taste and the increasingly assertive personal opinions of audiovisual products viewers or fans (Kayahara 2005, 64-67; Radiah and Hasuria 2009, 542-543). 
Furthermore with the proliferation of screens (e.g., television, smart phones and computers), human being's capability to receive and process information that was delivered through various semiotics channels, especially written text, has improved dramatically (Diaz-Cintas 2003, 197; Pérez-González 2007, 273). In this context, fansub has a competitive edge compared to professional subtitling set-ups because it involves viewers' contributions. The virtual world of the internet and the range of consumers involved have influenced and driven the development of fansub from workflow to the adoption of translation approaches (Pérez-González 2007, 266). Fansub is a labour of love of anime fans familiar with the material involved. Hence, those involved in fansubs are sensitive to the tastes, demands and requirements of fellow fans (Pérez-González 2007, 265). At the same time, the process also allows other fans who are the final consumers to be indirectly involved in the production of fansub through suggestions and feedback acquired via various channels on the internet such as social media portals, forums and other channels of communications, which help fansubbers to improve their subsequent works (Liew, Hasuria and Wan Rose 2011, 119). The application of translation approaches (such as gloss in source language, usage of footnotes as well as variety of fonts aligned with visual aesthetics) also proactively shapes the media experience in managing viewer expectation as well as creating a sense of familiarity with fansub work (Pérez-González 2012, 344-345).

The development of the fansub phenomenon which is related to the spread of anime culture across the globe has now spread to other audiovisual genres and products which has been reported in a number of recent scholarly works. Among the most recent writings that compared fansub works with conventional subtitles is the research by Verbruggen (2010) that identified the differences in approaches used in fansub and conventional subtitling work in terms of the translation of humourous elements in selected British and American series/sitcoms such as Fawlty Towers, Monty Python Flying Circus and Shrek. The study sought to identify to what extent the original forms/meanings were preserved in the translation of English puns and wordplay in Dutch subtitles. She posited that other translation techniques were applied to transfer these wordplay and metaphors, such as the changing of form, or by retaining the original language. In some instances, wordplay and metaphors are omitted in the subtitles.

Another piece of research that looked into the development of fansub phenomenon is by Tian (2011). He observed the activity of fansubbers in China who had produced subtitles for American television shows or series such as Survivor, The Big Bang Theory and Heroes. Through the analysis of selected fansub works, observation of fansub group community forum as well as personal interviews with a number of fansubbers in China, the study shows the vast differences between 
fansub and conventional subtitles in China. The differences are closely related to the cross-cultural interaction between Chinese and American cultures that shape the demand of fansub viewers. The resulting cross-cultural interaction between these two cultures highlighted in fansub also directly shapes viewers' perception of languages, humour as well as national identity/characteristics in other countries thus contributing towards globalisation.

The two studies above provide adequate evidence on the potential of the fansub phenomenon to spread to other genres beyond varieties of language pairings from its original intention of translating Japanese anime. With the rising numbers of fansub materials with consistent quality, such development also means greater research opportunity of the fansub phenomenon that is worth exploring in the future especially in the direction of studying viewers' reception.

Furthermore, the influence of fansub viewers in the distribution and marketing of audiovisual products can no longer be denied as observed in the development of anime streaming website, Crunchyroll (http://www.crunchyroll.com) (Miller 2017, 60-62). This streaming website was established in 2006 is reliant on anime series that has been fansubbed thus building its own close-knitted community of users who are actively involved in its growth and development. From the demand of their own community of viewers (ibid.), Crunchyroll began to form collaborations with animation companies in Japan directly in 2008 and has now established itself as the official/licensed distributor of new anime series that offer simultaneous broadcast streamings with subtitles. Many fans who were previously involved as fansubbers had also became official subtitlists for new anime series thus ensuring continuity of fansub viewing experience. The fansubs are officially licensed and retained in the distributed anime series that are streamed via internet.

In sum, it can be clearly established that fansub works which are produced and packaged for the distribution and consumption of internet users are different from conventional subtitling works for the same audiovisual products as it provides a more challenging yet meaningful viewers' experience (Pérez González 2007, 273) in comparison to conventional subtitlings that often minimise cultural elements in subtitles [Diaz-Cintas (2005) in Pérez González (2007, 264)]. In other words, audiovisual translations with its profound influence on viewers (Diaz-Cintas 2008, 4) can bring added value in audiovisual translations to viewers by going beyond its basic function, i.e., to transmit core messages and effects (Chiaro 2008, 243). 


\section{Conclusion}

As a fansubber, one also becomes a member of the greater fansubbing society and gain benefits from fansubbing activities. Therefore, fansubbers who can be considered as being a community within a community will take viewers' need and opinions in the production of fansub. This has a huge impact on the reception of fansub among viewers. In terms of culture, it can be argued that fansubbing activities can be classified as cultural mediation since fansubbers share information and resources through intercultural notes, or give explanation of specific terms of cultural practices and places, thus bridging the cultural gaps between viewers and Japanese language and culture.

Findings from recent research in the perception and reception of viewers towards the phenomena of fansubbing (e.g., Hasuria and Chow 2017; Gong 2017) show how perception is formed in fansub for it to be received by viewers. For example, English and Chinese fansubbers practice different framing mechanisms for their own social and cultural contexts (Hasuria and Chow 2017), thus utilising various modes of fansub presentation. These modes are determined based on viewers' demand and the importance of meaning towards the overall storyline. The meaning of the storyline can be perceived from the aspects of understanding, audience perspective as well as social and cultural contexts of the viewers. The findings also indicate that fansubbers of different languages have different understanding in defining "complete meaning" which refers to the meaning that needs to be presented to the audience. For instance, English fansub and Chinese fansub of the same show are likely to be dissimilar; what is emphasised in an English fansub may not be given the same emphasis in Chinese fansub and vice versa (Hasuria and Chow, 2017).

Gong (2017), in quoting Hsiao (2014) in a research on annotation (notes, additional gloss or commentary from translators) in English and Chinese for Japanese television series noted that annotations are included to provide additional information so that viewers are able to better understand the storyline. By doing so, the fansubbers are also closing the cultural gap between two languages by producing a more detailed fansub to enable viewers to better comprehend the storyline.

From the discussions above, it is clear that fansub is fast becoming more established with specific subtitling approaches which are vastly different from conventional subtitling technique and procedures. The differences, for instance, in its workflow and products, are capable of posting challenges to the existing conventional subtitling. Besides, the world of fansub will continue to develop visa-vis the rising demand of fans/viewers for anime series as well as giving a spill 
over effect to other audiovisual genres such as films or drama series which deal with a greater variety language pairings. Therefore, the perception and reception of viewers is one major aspect that is given due attention by fansubbers. The fansub phenomenon is deemed among the best examples in terms of the influence of multimedia technology development towards audiovisual translation and the viewers, who are also the consumers. Through more robust academic research, it is hoped that wider exposure, research and recognition can be given to the world of fansub, as it is a significant part in audiovisual translation research. The study about reception and perception of viewers in particular will give an idea about the potential of the reception of this new subtitling approach that can be applied and developed further in the subtitling for shows in DVD or on television.

Since fansub has a significant influence on the fans' viewing satisfaction, this paper proposes that more research is undertaken as an acknowlegement of fansubbing activities in the wider context of audiovisual translation research.

\section{Notes}

1. Please visit http://en.wikipedia.org/wiki/Fansub and http://en.wikipedia.org/wiki/ Fan_translation for introduction about fansub and fan translation.

2. See Diaz-Cintas and Muñoz Sánchez (2006), and Pérez-González (2007) for details of workflow in production of fansub.

3. See Karamitroglou (1998) for guidelines published by ESIST in http://www.esist.org/ ESIST\%20Subtitling\%20code.htm and Wan Ida Rahimah (2007) for professional subtitling practice.

\section{References}

Bold, B. 2011. The power of fan communities: An overview of fansubbing in Brazil. Tradução em Revista 11(2): 2. https://doi.org/10.17771/PUCRio.TradRev.18881

Bucaria, C. 2008. Acceptance of the norm or suspension of disbelief? The case of formulaic language in dubbese. In Between text and image: Updating research in screen translation, eds. D. Chiaro, C. Heiss and C. Bucaria, 149-163. Amsterdam/ Philadelphia: John Benjamin Publishing Company. https://doi.org/10.1075/ btl.78.16buc

Chiaro, D. 2008. Issues of quality in screen translation: Problem and solutions. In Between text and image: Updating research in screen translation, eds. D. Chiaro, C. Heiss and C. Bucaria, 241-256. Amsterdam/Philadelphia: John Benjamin Publishing Company. https://doi.org/10.1075/btl.78.24chi

Diaz-Cintas, J. 2003. Audiovisual translation in the third millennium. In Translation today: Trends and perspectives, eds. G. Anderman and M. Rogers, 192-204. Clevedon: Multilingual Matters Ltd. 
2005. Back to the future in subtitling. In Proceedings of the Marie Curie Euroconferences. MuTra 2005: Challenges of Multidimensional Translation, Saarbrücken, Germany, 2-6 May 2005.

. 2008. Audiovisual translation comes of age. In Between text and image: Updating research in screen translation, eds. D. Chiaro, C. Heiss and C. Bucaria, 1-9. Amsterdam/Philadelphia: John Benjamin Publishing Company. https://doi. org $/ 10.1075 / \mathrm{btl} .78 .02$ dia

Diaz-Cintas, J. and Muñoz Sánchez, P. 2006. Fansubs: Audiovisual translation in an amateur environment. The Journal of Specialised Translation 6(July): 37-52. http:// www.jostrans.org/issue06/issue06_toc.php (accessed 14 August 2014).

Ferrer Simo, M.R. 2005. Fansubs y scanlations: La influencia del aficionado en los criterios profesionales. Puentes 6: 27-43.

Gambier, Y. 2009. Perception and reception of audiovisual translation: Implications and challenges. In The sustainability of the translation field, eds. Hasuria Che Omar, Haslina Haroon and Aniswal Ghani, 40-57. Kuala Lumpur: Persatuan Penterjemah Malaysia.

Gong, X. 2017. On annotations in English and Chinese fan-subtitling: A case study of Japanese TV series Legal High. In Nilai penterjemahan dalam masyarakat, eds. Salinah Ja'afar et al., 767-777. Kuala Lumpur: Co-published by Universiti Malaya, Persatuan Penterjemah Malaysia, Dewan Bahasa dan Pustaka, Institut Terjemahan \& Buku Malaysia, Perbadanan Kota Buku.

Hasuria Che Omar and Chow Yean Fun. 2017. Penterjemahan pelbagai mod dalam program audiovisual anime Jepun. In Nilai penterjemahan dalam masyarakat, eds. Salinah Ja'afar et al., 69-92. Kuala Lumpur: Co-published by Universiti Malaya, Persatuan Penterjemah Malaysia, Dewan Bahasa dan Pustaka, Institut Terjemahan \& Buku Malaysia, Perbadanan Kota Buku.

Hatcher, J.S. 2005. Of otakus and fansubs: A critical look at anime online in light of current issues in copyright law. SCRIPT-ed 2(4): 546-571. https://doi.org/10.2966/ scrip.020405.514

Hsiao, C. 2014. The cultural translation of U.S television programs and movies: Subtitle groups as cultural brokers in China. PhD dissertation, University of California, USA.

Karamitroglou, F. 1998. A proposed set of subtitling standards in Europe. Translation Journal 2(2): 1-14. http://translationjournal.net/journal//04stndrd.htm (accessed 14 August 2014).

Kayahara, M. 2005. The digital revolution: DVD technology and the possibilities for audiovisual translation. The Journal of Specialised Translation 3: 64-74.

Liew Zhe Rong, Hasuria Che Omar and Wan Rose Eliza Abdul Rahman. 2011. Ada apa dengan fansub. In Globalisasi melalui penterjemahan, eds. Noor Ida Ramli, Norizah Ardi and Aini Aziz, 114-128. Kuala Lumpur: Persatuan Penterjemah Malaysia. .2013. Perbandingan tanggapan dan penerimaan penonton antara hasil penyarikataan umum dalam DVD dengan hasil 'fansub' dari sudut pendekatan ketersampaian (accessibility) Gambier (2009). In Pendidikan dan latihan penterjemah dan jurubahasa, eds. Hasuria Che Omar, Goh Sang Seong and Hasmidar Hassan, 87104. Kuala Lumpur: Persatuan Penterjemah Malaysia. 
Miller, L. 2017. Access and the construction of fan identity: Industry images of anime fandom. Participations: Journal of Audience \& Reception Studies 14(1): 49-66. http://www.participations.org/Volume\%2014/Issue\%201/4.pdf (accessed 28 January 2018).

O’Hagan, M. 2009. Evolution of user-generated translation: Fansubs, translation hacking and crowdsourcing. The Journal of Internationalization and Localization 1(1): 94121. https://doi.org/10.1075/jial.1.04hag . 2010. Japanese TV entertainment: Framing humour with open caption telop. In Translation, humour and the media (vol. 2), ed. D. Chiaro, 70-88. London/New York: Continuum International Publishing Group.

Pérez-González, L. 2007. Fansubbing anime: Insights into the butterfly effect of globalisation on audiovisual translation. Perspectives: Studies in Translatology 14(4): 260-277. https://doi.org/10.1080/09076760708669043

.2012. Amateur subtitling and the pragmatics of spectatorial subjectivity. Language and Intercultural Communication 12(4): 335-352. https://doi.org/10.1080/1470847 7.2012.722100

Radiah Yusoff and Hasuria Che Omar. 2009. Satu kajian kes terhadap pemahaman filem dan kepentingan penterjemahan. In Kelestarian bidang penterjemahan, eds. Hasuria Che Omar and Rokiah Awang, 537-545. Kuala Lumpur: Persatuan Penterjemah Malaysia.

Rush, A. 2009. Otaku creations: The participatory culture of fansubbing. Digital imageries: Culture and reception. Kinephanos Journal 1: 1-18. http://web.mac.com/paraffilm/ iWeb/Kinephanos/Otaku_files/Otaku_v1n1.pdf (accessed 25 February 2018).

Tian, Y. 2011. Fansub cyber culture in China. Masters thesis, Georgetown University, Georgetown, Washington, USA. https://search.proquest.com/openview/df33ed91b 9b78c80b082df8e29e90e12/1?pq-origsite=gscholar\&cbl=18750\&diss=y (accessed 28 January 2018).

Verbruggen, N. 2010. The translation of wordplay in fansubs and original subtitles: A comparative study. Masters thesis, Ghent University, Belgium. http://lib.ugent. be/fulltxt/RUG01/001/457/866/RUG01-001457866_2011_0001_AC.pdf (accessed 28 January 2018).

Wan Ida Rahimah. 2007. Penyuntingan dalam penyarikataan. In Penyarikataan: Satu kaedah penterjemahan audiovisual, ed. Hasuria Che Omar, 43-54. Kuala Lumpur: Institut Terjemahan Negara Malaysia Berhad. 